\title{
EFEKTIVITAS METODE 'IBRAH MAU'IZHAH DALAM \\ MODEL PEMBELAJARAN STUDENT TEAMS \\ ACHIEVEMENT DIVISIONS TERHADAP PRESTASI BELAJAR SISWA \\ PADA MATA PELAJARAN AKIDAH AKHLAK DI MTS PLUS DARUL HUFADZ JATINANGOR
}

\author{
Lulu Maknun, ${ }^{*}$ Udin Supriadi, dan Mokh. Iman Firmansyah \\ Universitas Pendidikan Indonesia \\ *E-mail: lulumaknun11@gmail.com
}

\begin{abstract}
This present study is conducted based on the ineffectiveness of learning method and model on Akidah Akblake subject in class VIII. This study aims at identifying the effectiveness of 'Ibrah Mau'i'ah method in STAD learning model on Akidah Akblak subject in an attempt to improve learning achievements. The method employed in this present study was quasi-experimental method of nonequivalent control group design type using quantitative approach and the instruments were in the form of a written multiple choice in which the results of this test were analyzed using a descriptive statistic approach. The results of this study showed that 'Ibrah Mau'izah method in the STAD learning model was assumed to be effective in improving students' learning achievement. As suggestion for the further studies, it is necessary to carry out a comparative study using other models and a further study in relation to morals.
\end{abstract}

Keywords: 'Ibrah Mau'izah Method, STAD Model, Akidah Akblak Learning Achievement.

\begin{abstract}
ABSTRAK
Penelitian ini dilatarbelakangi belum optimalnya metode dan model pembelajaran pada mata pelajaran Akidah Akblake kelas VIII. Tujuan dari penelitian ini untuk mengetabui efektivitas metode 'ibrah mauizhah dalam model pembelajaran STAD untuk meningkatkan prestasi belajar. Melalui metode quasi eksperimen jenis nonequivalent control group design dengan pendekatan kuantitatif serta instrumen bentuk tertulis piliban ganda yang hasilnya dianalisis secara deskriptif statistik, penelitian menunjukekan metode ibrah mauizhah dalam model pembelajaran STAD efektif dalam meningkatkan prestasi belajar siswa. Rekomendasi dari penelitian ini diperlukan penelitian perbandingan dengan model lain serta penelitian lanjutan kaitannya dengan akblak.
\end{abstract}

Kata Kunci: Metode Ibrah Manizhah, Model STAD, Prestasi Belajar Akidah Akblak. 


\section{PENDAHULUAN}

Iman dan taqwa serta akhlak mulia merupakan dua dari banyak aspek yang ditekankan UndangUndang Nomor 20 Tahun 2003 pasal 3. Kedua aspek tersebut sebagaimana pula merupakan visi dari mata pelajaran PAI. Dalam Permendiknas No. 22 tahun 2006 dijelaskan bahwa visi mata pelajaran PAI untuk mewujudkan manusia yang bertakwa kepada Allah SWT dan berakhlak mulia, serta bertujuan untuk menghasilkan manusia yang jujur, adil, berbudi pekerti, etis, saling menghargai, disiplin, harmonis dan produktif, baik personal maupun sosial. Keberhasilan output dari mata pelajaran PAI tidak terlepas dari proses pembelajaran yang berkualitas. Banyak komponen yang mempengaruhi kualitas suatu pembelajaran. Salah satu komponen itu adalah metode pembelajaran. Prastowo (2014, hal. 166) mengemukakan bahwa metode adalah kunci dan cara untuk melakukan pekerjaan. Sedangkan Umar (2010, hal. 180) serta Djamarah dan Zain (2006, hal. 46) menjelaskan bahwa metode adalah cara yang dipergunakan untuk mencapai tujuan yang telah ditetapkan. Dalam hal ini, kedudukan metode sangat penting dalam proses pembelajaran, tidak terkecuali pada mata pelajaran PAI.

Metode pembelajaran dapat diartikan sebagai cara yang digunakan untuk mengimplementasikan rencana yang sudah disusun dalam bentuk kegiatan nyata dan praktis untuk mencapai tujuan pembelajaran (Komalasari, 2011, hal. 56). Uno (2009, hal. 2) menjelaskan bahwa metode pembelajaran lebih bersifat prosedural, yaitu berisi tahapan tertentu. Metode pembelajaran mengharuskan siswa untuk aktif serta terintegrasi dengan penilaian pembelajaran siswa (Alsardary \& Blumberg, 2009, hal 409410). Penilaian pembelajaran siswa dalam hal ini adalah mengenai prestasi belajar siswa. Prestasi belajar yaitu penguasaan pengetahuan atau keterampilan yang dikembangkan oleh mata pelajaran, lazimnya ditunjukkan dengan nilai tes atau angka nilai yang diberikan oleh guru (Rusman, 2011, hal. 200).

Metode dianggap sebagai cara yang keberhasilannya adalah di dalam belajar, atau sebagai alat yang menjadikan mengajar menjadi efektif (Wahab A. A., 2008, hal. 36). Efektif dalam hal ini berarti menyelesaikan sesuatu dengan baik (McQueen \& Webber, 2013, hal. 716). Menurut Prokopenko dalam Armen (2009, hal. 130), Widdah, dkk. (2012, hal. 55), efektivitas mengacu kepada pencapaian target suatu sasaran program. Reigeluth (1983) dalam Said (2006, hal. 98) menyatakan bahwa efektifitas ini diwujudkan dalam bentuk skor hasil belajar. Dengan demikian, efektifitas pembelajaran terletak pada strategi pembelajaran yang digunakan pada saat proses pembelajaran (Cornford, 2002, hal 366).

Menurut Nasih dan Kholidah (2009, hal. 33) banyak kalangan menilai bahwa metode pembelajaran PAI yang berjalan saat ini masih sebatas transfer nilai dengan 
pendekatan hafalan. Proses pembelajaran yang terjadi cenderung didominasi pembelajaran yang bersifat konvensional. Siswa menerima informasi atau materi dari guru dengan cara menghafal informasi berupa konsep-konsep sehingga terjadi apa yang disebut sebagai belajar hafalan (Alfiah, 2014, hal. 236). Akhirnya siswa menjadi tidak kreatif dan kritis dalam belajar serta akan mempengaruhi pula pada prestasi belajar dan perilakunya. Akibat lain yang ditimbulkan seperti yang diungkapkan oleh Faisol (2013) tentang seorang siswa yang dikenal sebagai siswa teladan di sekolahnya, mempunyai pribadi yang disiplin, ternyata siswa tersebut terlibat dalam tindak pidana pencurian sepeda motor. Contoh kasus tersebut tidak terlepas dari upaya guru untuk mendidik siswanya menjadi pribadi yang lebih baik. Selain itu, permasalahan yang terjadi mungkin saja karena proses pembelajaran di kelas. Berdasarkan studi pendahuluan di MTs Plus Darul Hufadz, proses pembelajaran di kelas masih dengan menggunakan metode ceramah dan hanya berpusat pada guru saja atau teacher centre. Siswa menjadi kurang aktif dan kurang termotivasi untuk mengikuti pelajaran, guru cenderung menggunakan model penugasan sehingga siswa tidak mendapat bimbingan dalam proses pembelajaran, dan suasana kelas yang monoton. Hal ini menyebabkan rendahnya prestasi belajar, khususnya pada mata pelajaran Akidah Akhlak.

Dalam hal ini guru harus mempunyai strategi pembelajaran yang efektif, terutama dalam hal metode dan model pembelajaran. Salah satu upaya untuk mencapai keefektifan proses pembelajaran adalah dengan menggunakan metode yang tepat. Metode yang efektif adalah metode yang bervariasi untuk mencapai tujuan pembelajaran (Mulyasa, 2009, hal. 107). Mujib dan Mudzakir (2014, hal. 166167) mengemukakan bahwa agar proses dan hasil pembelajaran lebih berdaya guna dan berhasil serta menimbulkan kesadaran siswa untuk mengamalkan ajaran Islam maka seharusnya menggunakan metode pendidikan Islam yang didasarkan kepada nilai-nilai yang ada dalam Alquran. Melalui metode pendidikan Islam diharapkan bisa terintegrasinya antara perbuatan, akal, dan hati (Alavi, 2013, hal. 11-12).

Salah satu jenis metode pendidikan qurani yaitu metode Tbrah Maw'zhah. Metode 'Tbrab Mau'iz̧ah menurut An-Nahlawi (1989, hal. 403) yaitu pemberian nasehat dan pengingatan akan kebaikan dan kebenaran dengan cara menyentuh qalbu dan menggungah untuk mengamalkannya. Majid (2012, hal. 136) menambahkan bahwa mau'iz̧ berarti juga peringatan. Peringatan jika dalam bahasa Arab berarti tadzkirah. Sedangkan menurut Tafsir (2011, hal. 145) mau'izhah ialah nasihat yang lembut yang diterima oleh hati dengan cara menjelaskan pahala atau ancaman. Metode 'ibrah mau'izhah juga berarti suatu cara menyampaikan materi pelajaran melalui tutur kata yang berisi nasihat-nasihat dan pengingatan tentang baik buruknya sesuatu (Syahidin, 2009, hal. 111). 
Selain itu, dalam pembelajaran seorang guru dituntut untuk dapat menghidupkan kelas sehingga pembelajaran di kelas bersifat aktif dan bermakna. Remus (1978, hal. 55) menyatakan bahwa pembelajaran yang efektif adalah pembelajaran yang bermakna bagi siswa. Dalam menyampaikan materi pembelajaran, selain diperlukan metode, juga diperlukan model pembelajaran yang efektif. Model pembelajaran dapat didefinisikan sebagai kerangka konseptual yang melukiskan prosedur sistematis dalam mengorganisasikan pengalaman belajar untuk mencapai tujuan belajar (Suprijono, 2012, hal. 46). Dalam model pembelajaran terdapat suatu sintaks atau langkahlangkah yang sistematis dan urut tertentu (Suyono \& Hariyanto, 2012, hal. 23). Pada dasarnya model pembelajaran merupakan bingkai pembelajaran yang tergambar dari awal sampai akhir. Dari beragam model pembelajaran, salah satunya adalah model pembelajaran cooperative learning tipe STAD.

Trianto (2012, hal. 68-69) mengemukakan bahwa model STAD merupakan salah satu tipe dari model pembelajaran kooperatif dengan menggunakan kelompok-kelompok kecil dengan menggunakan jumlah anggota tiap kelompok 4-5 orang siswa secara heterogen. Balfakih (2003, hlm 610) mengemukakan bahwa dalam pembelajaran menggunakan model STAD aktivitas siswa banyak terlibat pada kegiatan tim atau kelompok. Dalam STAD mendorong siswa untuk terbiasa bekerja sama dan saling membantu dalam menyelesaikan suatu masalah, tetapi pada akhirnya bertanggung jawab secara mandiri (Warsono \& Hariyanto, 2012, hal. 197). Ghaith (2004, hal 82) menyatakan bahwa model STAD terdiri dari 4 tahapan pembelajaran yaitu (1) penyajian materi oleh guru, (2) belajar kelompok, (3) tes individual, dan (4) penghargaan kelompok. Sementara itu, menurut Alma, dkk. (2009, hal. 83-84) ada lima langkah yang dilakukan pada STAD yaitu (1) penyajian materi, (2) kegiatan kelompok, (3) tes individual, dan (4) perhitungan skor perkembangan individu, dan penghargaan kelompok.

Melalui metode 'ibrah man'izhah dalam model pembelajaran kooperatif tipe STAD diharapkan: (1) Tingginya aktivitas siswa dalam proses pembelajaran sehingga prestasi belajar siswa meningkat dalam mata pelajaran Akidah Akhlak pada bab Keteguhan Iman Sahabat Abu Bakar Ash-Shidiq dan bab Akhlak Terpuji (Husnuzhan, Tawadhu', Tasamuh, dan Ta'awun) (2) Dapat terinternalisasinya nilai-nilai sehingga perilaku siswa berbanding lurus dengan pengetahuan yang didapatkan. Dengan demikian, penulis merasa tergugah untuk melakukan penelitian tentang metode ibrah Mau'iz̧bah dalam model pembelajaran STAD dengan menuangkannya dalam sebuah penelitian yang berjudul Efektivitas Metode Tbrah Mau'iz̧ah dalam Model Pembelajaran Student Teams Achievement Divisions Terhadap Prestasi Belajar Siswa pada Mata Pelajaran Akidah Akhlak (Studi Quasi Eksperimen di Kelas VIII MTs Plus Darul Hufadz Jatinangor Sumedang). 


\section{METODE PENELITIAN}

Dalam penelitian

ini, pendekatan penelitian menggunakan penelitian kuantitatif. Menurut Sugiyono (2016, hlm. 14) pendekatan kuantitatif adalah pendekatan penelitian yang digunakan untuk meneliti pada populasi atau sampel dengan teknik pengambilan sampel tertentu, pengumpulan data menggunakan instrumen penelitian serta analisis data bersifat kuantitatif/statistik dengan tujuan untuk menguji hipotesis yang telah ditetapkan. Peneliti menggunakan pendekatan kuantitatif untuk mengumpulkan data berupa angka. Karena penelitian ini memiliki tujuan untuk mengetahui efektifitas metode 'Ibrah Mau'izah dalam model Student Teams Achievement Divisions terhadap prestasi belajar siswa pada mata pelajaran Akidah Akhlak, maka dibutuhkan cara menggunakan statistik dalam pengolahan data.

Metode penelitian yang digunakan adalah metode eksperimen bentuk quasi eksperimen. Peneliti dalam hal ini menggunakan metode quasi eksperimen untuk mencari pengaruh antara kelas eksperimen yang diberikan perlakuan (treatment) dengan metode ibrah mau'izhah dalam model pembelajaran STAD dengan kelas kontrol yang tidak diberikan perlakuan (treatment) (Sugiyono, 2016, hal. 107). Desain penelitian yang digunakan adalah Nonequivalent Control Group Design. Dengan desain ini, baik kelompok eksperimen maupun kelompok kontrol dibandingkan (Emzir, 2015, hal. 102). Dua kelompok yang ada diberi pre-test, kemudian diberikan perlakuan, dan terakhir diberikan post-test.

Teknik pengambilan sampel yang digunakan adalah nonprobability sampling tipe sampling purposive. Sampling purposive adalah teknik penentuan sampel dengan pertimbangan tertentu (Darwis, 2014, hal. 52). Ditentukan bahwa yang dijadikan sampel adalah kelas VIII-C (kelas kontrol) berjumlah 24 siswa dan kelas VIII-D (kelas eksperimen) berjumlah 24 siswa. Pengambilan sampel ini berdasarkan bahwa kedua kelompok tersebut memiliki kesetaraan nilai yang tinggi dalam hasil Ulangan Akhir Semester pertama (ganjil) pada mata pelajaran Akidah Akhlak tahun pelajaran 2016/2017. Adapun instrumen yang penelitian yang digunakan adalah tes tulis bentuk pilihan ganda dengan jumlah 50 butir soal. Teknik analisis data menggunakan analisis deskriptif dan statistik.

\section{HASIL PENELITIAN DAN PEMBAHASAN}

\section{A. Efektivitas}

Menurut Kamus Besar Bahasa Indonesia (2008, hlm. 352) efektivitas berasal dari kata efektif yang artinya ada efeknya, akibatnya, pengaruhnya, kesannya, dan berhasil setelah melakukan suatu usaha atau tindakan. Menurut McQueen dan Webber (2013, hlm. 716) Efektif berakar pada bahasa Latin untuk pencapaian atau kinerja, efektif juga berarti menyelesaikan sesuatu dengan baik.

TARBAWY: Indonesian Journal of Islamic Education - Vol. 4 No. 2 (2017) | 111 
Sementara itu, menurut Widdah, dkk. (2012, hlm. 55) efektivitas merupakan "refleksi kemampuan untuk mempengaruhi terjadinya suatu produk. Efektivitas mengacu kepada pencapaian target suatu sasaran program". Menurut Reigeluth (dalam Said, 2006, hlm. 98) efektif adalah berapa banyak tujuan pembelajaran yang telah dicapai oleh siswa. Efektivitas ini diwujudkan dalam bentuk skor hasil belajar. Kemudian menurut Prokopenko (dalam Armen, 2009, hlm. 130) efektivitas adalah suatu keadaan yang menunjukkan tingkat keberhasilan mencapai tujuan. Sedangkan Mulyasa (2007, hlm. 82) berpendapat bahwa:

Efektivitas berkaitan dengan terlaksananya semua tugas pokok, tercapainya tujuan, ketepatan waktu, dan adanya partisipasi aktif dari anggota. Efektivitas juga berkaitan erat dengan perbandingan antara tingkat pencapaian tujuan dengan rencana yang telah disusun sebelumnya.

Efektifitas merupakan ukuran
seberapa jauh tingkat output,
kebijakan dan prosedur dari organisasi
mencapai tujuan yang ditetapkan.
(Bungkaes, Posumah, \& Kiyai, 2013, hlm. 9). Sementara itu, efektivitas juga merupakan suatu metode dengan cara membandingkan untuk mencari alternatif terbaik (Pharmd \& Pharmd, 2016, hlm. 3). Budiani (2009, hlm. 54).menambahkan bahwa efektifitas adalah keseuaian antara output dengan tujuan yang ditetapkan.

Dari penjelasan di atas, efektivitas merupakan hasil dari pencapaian suatu tujuan dengan melakukan cara untuk mencapai tujuan tersebut. Dalam hal ini efektivitas yang dimaksud adalah efektivitas dalam proses pembelajaran. Efektifitas pembelajaran adalah yang menghasilkan belajar yang bermanfaat dan sesuai dengan tujuan pembelajaran (Miarso, 2004, hlm. 536). Cornford (2002, hlm. 366) berpendapat bahwa efektivitas pembelajaran terletak pada strategi pembelajaran yang digunakan pada saat proses pembelajaran.

Riyanto / (2003, hlm. memaparkan bahwa efektifitas pembelajaran adalah usaha yang membuahkan hasil atau menghasilkan belajar yang bermanfaat dan bertujuan bagi para siswa melalui pemakaian prosedur yang tepat. Sementara itu, menurut Sadirman (dalam Trianto, 2012, hlm. 20) efektivitas pembelajaran adalah hasil guna yang diperoleh setelah pelaksanaan proses pembelajaran. Untuk mengetahui keefektifan mengajar, dengan memberikan tes, sebab hasil tes dapat dipakai untuk mengevaluasi berbagai aspek proses pengajaran. Salah satu upaya untuk mencapai keefektifan proses pembelajaran adalah dengan menggunakan metode yang tepat. Metode yang efektif adalah metode yang bervariasi untuk mencapai tujuan pembelajaran (Mulyasa, 2009, hlm. 107).

Berdasarkan pemaparan di atas, dapat disimpulkan bahwa efektivitas berarti kemampuan atau cara untuk mencapai tujuan yang diharapkan. Dalam proses pembelajaran, efektivitas dilihat dari kesesuaian antara tujuan yang telah ditetapkan dalam pembelajaran dengan hasil yang 
diperoleh pada saat evaluasi. Dalam hal ini, efektifitas suatu metode dan model pembelajaran, semakin tinggi ketercapaian tujuan pembelajaran maka semakin tingkat keefektifannya.

\section{B. Metode 'Ibrah Mau'izah}

\section{Pengertian}

Secara etimologi, metode berasal dari kata method yang berarti suatu cara kerja yang sistematis untuk memudahkan pelaksanaan kegiatan dalam mencapai suatu tujuan. Metode pembelajaran berarti suatu cara atau sistem yang digunakan dalam pembelajaran yang bertujuan agar anak didik dapat mengetahui, memahami, mempergunakan, menguasai bahan pelajaran tertentu (Nasih \& Kholidah, 2009, hlm. 29). Asyafah (2010, hlm. 238) menjelaskan bahwa metode adalah suatu cara atau prosedur yang sistematis dan praktis untuk mencapai tujuan tertentu. Secara umum pengertian metode diartikan sebagai cara yang digunakan untuk mencapai tujuan yang telah ditetapkan (Prastowo, 2014, hlm. 166).

Umar (2010, hlm. 180) mengemukakan bahwa "metode atau metoda berasal dari bahasa Yunani, yaitu metha dan hodos. Metha berarti melalui atau melewati dan hodos berarti jalan atau cara. Metode berarti jalan atau cara yang harus dilalui untuk mencapai tujuan tertentu". Sependapat dengan Umar, Majid (2012, hlm. 132) menjelaskan bahwa metode adalah cara yang dipergunakan untuk mencapai tujuan yang telah ditetapkan. Yaumi (2013, hlm. 205) menjelaskan bahwa metode merupakan upaya untuk mengimplementasikan rencana yang sudah disusun dalam kegiatan nyata agar tujuan yang telah disusun tercapai secara optimal. Senada dengan hal ini, Iskandarwassid dan Sunendar (2011, hlm. 56). mengemukakan bahwa metode adalah cara kerja yang bersistem untuk memudahkan pelaksanaan suatu kegiatan guna mencapai tujuan yang telah ditetapkan.

Sementara itu, Uno (2009, hlm. 2) menjelaskan bahwa metode pembelajaran didefinisikan sebagai cara yang digunakan guru, yang dalam menjalankan fungsinya merupakan alat untuk mencapai tujuan pembelajaran. Metode pembelajaran lebih bersifat prosedural, yaitu berisi tahapan tertentu.

Sedangkan menurut Komalasari (2011, hlm. 56) metode pembelajaran dapat diartikan sebagai "cara yang digunakan untuk mengimplementasikan rencana yang sudah disusun dalam bentuk kegiatan nyata dan praktis untuk mencapai tujuan pembelajaran”. Wahab (2008, hlm. 36) menambahkan bahwa "metode dianggap sebagai cara atau prosedur yang keberhasilannya adalah di dalam belajar, atau sebagai alat yang menjadikan mengajar menjadi efektif'.

Dari pemaparan di atas, dapat disimpulkan bahwa metode pembelajaran adalah cara yang digunakan oleh seorang guru, meliputi langkah-langkah yang sistematis untuk mencapai suatu tujuan pembelajaran

TARBAWY: Indonesian Journal of Islamic Education - Vol. 4 No. 2 (2017) | 113 
yang diharapkan. Berbicara mengenai metode, dalam Islām terdapat beberapa metode pembelajaran yang berasal dari Quran, yang disebut dengan metode Qurani. Metode Qurani yaitu suatu cara atau tindakantindakan dalam lingkup peristiwa pendidikan yang terkandung dalam Alquran dan Sunnah (Syahidin, 2009, hlm. 44). Salah satu metode pendidikan Qurani yaitu metode Tbrah Mau'izạh.

An-Nahlawi (1989, hlm. 389390) menjelaskan mengenai pengertian ibrah secara istilah yaitu:

Tbrab adalah salah satu mașdar (pokok kata) dari 'abara. Sedangkan secara istilah ibrah ialah suatu kondisi untuk mengetahui intisari sesuatu perkara yang disaksikan, diperhatikan, diinduksi, ditimbangtimbang, diukur, dan diputuskan oleh manusia secara nalar, sehingga kesimpulannya dapat mempengaruhi hati menjadi tunduk kepadanya, lalu hal itu mendorongnya kepada perilaku berpikir dan sosial yang sesuai.

Sedangkan metode ibrah menurut Syahidin (2009, hlm. 110) yaitu:

Suatu cara yang dapat membuat kondisi psikis seseorang (siswa), mengetahui intisari perkara yang mempengaruhi perasaannya, yang diambil dari pengalamanpengalaman orang lain atau pengalaman hidupnya sendiri sehingga sampai pada tahap perenungan, pengahayatan, dan tafakur yang dapat menumbuhkan amal perbuatan.
Adapun tujuan pedagogis dari ibrab menurut an-Nahlawi (1989, hlm. 390). yaitu :

Mengantarkan pendengar kepada suatu kepuasan pikir akan salah satu perkara 'aqidah, yang di dalam qalbu menggerakkan atau mendidik perasaan Rabbaniyah (ketuhanan), sebagaimana menanamkan, mengokohkan, dan menumbuhkan 'aqidah tauhid, ketundukan kepada syara' Allāh dan kepatuhan kepada segala perintah-Nya.

Sedangkan kata Mau'izah secara bahasa dikemukakan oleh an-Nahlawi (1989, hlm. 403) yaitu sebagai berikut:

W'a'azahu, ya'izuhu, wa'żan, wa'iżatan, wa mau'izatan; mengingatkannya akan apa yang dapat melembutkan qalbunya, yang berupa pahala dan siksa, sehingga dia menerima nasihat.

Majid (2012, hlm. 136) menambahkan bahwa mau'iz̧ah berarti juga peringatan. Peringatan jika dalam bahasa Arab berarti tazkirah. Sedangkan menurut Tafsir (2011, hlm. 145) mau'izah ialah "nasihat yang lembut yang diterima oleh hati dengan cara menjelaskan pahala atau ancaman". "Metode Mau'izah berarti suatu cara menyampaikan materi pelajaran melalui tutur kata yang berisi nasihat-nasihat dan pengingatan tentang baik buruknya sesuatu" (Syahidin, 2009, hlm. 111). Dalam menyingkap makna Quraninya, AnNahlawi (1989, hlm. 403) memaparkan bahwa" mau'izah adalah pemberian nasehat dan pengingatan akan kebaikan dan kebenaran dengan cara 
menyentuh qalbu dan menggungah untuk mengamalkannya".

Dari pemaparan di atas, dapat disimpulkan bahwa metode Tbrah Mau'izah adalah metode dengan cara menyampaikan materi pelajaran melalui nasihat dan mengambil pelajaran atau hikmah dari setiap pembelajaran sehingga menyentuh qalbu dan dapat menumbuhkan amal perbuatan siswa.

\section{Bentuk 'Ibrah dan Mau'izah}

Adapun bentuk íbrah dan man'izah yaitu sebagai berikut:

a. Bentuk Tbrah

1) Tbrah dari Kisah

Penggunaan metode 'ibrah

dari kisah tujuannya ialah pengambilan pelajaran, karena di dalam kisah tidak hanya mengandung peristiwa semata, tetapi mengandung nilai-nilai religius, ketuhanan dan mengandung nilai historis. Oleh karena itu, 'ibrah melalui kisah ini memiliki daya yang dapat menggugah perasaan dan menumbuhkan amal perbuatan (Syahidin, 2009, hlm. 113).

Implikasi pedagogis ibrah dari kisah menurut an-Nahlawi (1989, hlm. 392) yaitu menanamkan akhlak Islamiyah dan perasaan Rabbaniyah kepada anak didik. Di antaranya dengan melakukan cara sebagai berikut:

a) Mengajukan pertanyaan. Melalui pertanyaan itu diharapkan mereka dapat menangkap ibrah dari setiap kisah Qurani. b) Mengajukan pertanyaanpertanyaan lain yang dimaksudkan untuk membimbing perasaan mereka menangkap dan menghayati isi serta pesan yang tersirat dalam kisah tersebut.

c) Membimbing untuk membandingkan antara sikap para pelaku kisah itu dengan sikap para pelajar atau masyarakat sehari-hari.

2) Tbrah dari Makhluk Allāh dan

Nikmatnya

Pengambilan pelajaran dari makhluk Allāh, baik manusia, hewan, tumbuhan, dan lain-lain, yang di dalamnya terdapat berbagai kenikmatan. Tbrah dengan cara ini dapat dengan langsung merujuk pada ayat-ayat Alquran maupun pada gejalagejala alam (Syahidin, 2009, hlm. 113).

Tuntutan pedagogis ibrah dari makhluk Allāh dan nikmatnya menurut An-Nahlawi (1989, hlm. 394) yaitu:

Hendaknya guru selalu melatih akal para siswa untuk merenungkan berbagai keajaiban yang diciptakan Allāh, terutama keajaiban yang ada di sekeliling kita dan kita amati dalam kehidupan setiap hari yang merupakan bukti hikmah (kebijaksanaan) Allāh dan ketelitian pembuatan-Nya.

3) Tbrab Melalui Peristiwa Sejarah

Penggunaan metode ibrah diharapkan dapat menggugah perasaan heran, takjub, kagum, dan 
menyentuh qalbu yang melahirkan perenungan, penghayatan, dan tafakur yang dapat menumbuhkan amal sholeh. Maka dari itu guru hendaknya menggugah akal para siswa untuk merenungkan nilai-nilai yang terdapat dalam ibrah yang dibawakannya. Hal ini dimaksudkan agar membawa mereka berpikir secara baik (Syahidin, 2009, hlm. 114).

\section{b. Bentuk Mau'izah}

\section{1) Nasihat langsung}

Nasihat berasal dari kata "nașaha" yang mengandung arti "keterlepasan dari segala kotoran dan tipuan. Menurut istilah, nasihat merupakan sajian gambaran tentang kebenaran dan kebajikan, dengan maksud mengajak orang yang dinasihati untuk menjauhkan diri dari bahaya dan membimbingnya ke jalan yang bahagia dan berfaedah baginya. Metode Man'izah bentuk nasihat ini memiliki keistimewaan antara lain dapat membuka jalan untuk mempengaruhi perasaan dan pikiran yang mengarah pada kebajikan (An-Nahlawi, 1989, hlm.404).

\section{2) Tażkir}

Bentuk kedua metode Mau'izah yaitu tażkir (peringatan) yang dimaksud ialah mengingatkan berbagai makna dan kesan yang dapat membangkitkan perasaan, emosi untuk segera beramal șaleh, dekat dengan Allāh dan melaksanakan segala perintah-Nya.
Adapun bentuk tażkir yaitu: Tażkir akan kematian, Tażkir akan penyakit, Tażkir akan hari penghisaban (An-Nahlawi, 1989, hlm. 406-408).

Penggunaan metode Mau'izah bentuk tażkir ini membimbing fitrah potensi baik, agar tetap pada kebaikan dan berkembang menuju kesempurnaan, serta menghadang potensi buruk agar tidak berkembang. Agar metode ini benar-benar berpengaruh atau menggugah qalbu dan pikiran siswa, sebaiknya dilakukan dalam situasi yang tepat.

1. Kondisi Awal Prestasi Belajar Siswa Kelas Eksperimen dan Kelas Kontrol

Dari hasil analisis yang telah dilakukan, diketahui bahwa kondisi awal prestasi belajar siswa kelas eksperimen ditemukan bahwa rata-rata nilai pre-test adalah 46,33 dan nilai interpretasinya kurang. Kemudian untuk distribusi frekuensi pre-test-nya diketahui bahwa di kelas eksperimen tidak terdapat siswa yang memiliki nilai interpretasi sangat baik. Kemudian 1 siswa memiliki interpretasi baik atau $4 \%$ dari jumlah seluruh siswa yang mengikuti pre-test di kelas eksperimen. Selanjutnya terdapat 1 siswa yang memiliki interpretasi cukup atau 4\% dari jumlah seluruh siswa yang mengikuti pre-test di kelas eksperimen dan terdapat 22 siswa yang memiliki interpretasi kurang atau 92\% dari jumlah seluruh siswa yang mengikuti pre-test di kelas eksperimen. 
Dari hasi perhitungan pre-test diperoleh sebanyak 48\% siswa kelas eksperimen yang memahami bab Keteguhan Iman Abu Bakar ashShiddiq. Jika dilihat dari indikator pada bab ini, yang dipahami oleh siswa pada indikator pertama sebesar $48 \%$, indikator kedua sebesar 35\%, indikator ketiga sebesar $59 \%$, dan indikator keempat sebesar 50\%.

Sedangkan siswa kelas eksperimen yang memahami bab Husnuzhan, Tawadhu, Tasamuh, dan Ta'awun sebanyak 40\%. Jika dilihat dari indikator yang ada pada bab ini, sebesar $46 \%$ yang dipahami siswa pada indikator pertama, sedangkan pada indikator kedua sebesar 43\%, kemudian indikator ketiga sebesar $41 \%$, dan indikator keempat sebesar $29 \%$.

Mengenai kondisi awal prestasi belajar siswa kelas kontrol, diketahui bahwa rata-rata nilai pre-test sebesar 53,83 dan interpretasi nilainya kurang. Selanjutnya mengenai distribusi frekuensi pre-test kelas kontrol diketahui tidak terdapat siswa yang memiliki interpretasi nilai sangat baik dan yang memiliki interpretasi nilai baik sebanyak 3 orang atau $12 \%$, selanjutnya yang memiliki interpretasi nilai cukup terdapat 5 siswa atau $21 \%$, dan yang memiliki interpretasi nilai kurang sebanyak 16 siswa atau $67 \%$.

Selanjutnya mengenai pemahaman siswa kelas kontrol terhadap bab Keteguhan Iman Abu Bakar ash-Shiddiq ketika pre-test sebanyak 59\%. Jika dilihat dari indikator pada bab ini yang dipahami oleh siswa yaitu indikator pertama sebanyak 56\%, indikator kedua sebanyak 43\%, indikator ketiga sebanyak $71 \%$, indikator keempat sebanyak $65 \%$.

Sedangkan mengenai bab Husnuzhan, Tawadhu, Tasamub, dan Ta'awun yang dipahami oleh siswa kelas kontrol sebanyak 43\%. Jika dilihat dari indikator yang ada di bab ini, sebanyak $57 \%$ yang dipahami siswa pada indikator pertama, sedangkan pada indikator kedua sebanyak 46\%, kemudian indikator ketiga sebanyak $38 \%$, dan indikator keempat sebanyak 33\%.

Kemudian untuk mengetahui adanya perbedaan yang signifikan atau tidak antara hasil pre-test kelas eksperimen dan kontrol, dicari dengan uji independent sample t test karena pada pengujiannya sebelumnya telah diketahui bahwa distribusi data pre-test kelas eksperimen dan kontrol normal dan homogen. Berdasarkan uji independent sample $\mathrm{t}$ test, diperoleh nilai sig.( 2 tailed) sebesar 0,079 yang artinya lebih besar dari 0,05. Maka, sesuai dengan ketentuan bahwa tidak terdapat perbedaan yang signifikan dari nilai rata-rata antara kelas eksperimen dan kelas kontrol.

Dari uji independent sample t test tersebut dapat disimpulkan bahwa siswa kelas eksperimen dan kontrol memiliki pemahaman yang relatif sama sebelum dilakukan treatment dengan menggunakan metode Tbrah Mauiz̧ah dalam model pembelajaran Student Teams Achievement Divisions di kelas eksperimen, dan metode ceramah di kelas kontrol. Hal ini berarti antara siswa kelas eksperimen dan kontrol memiliki kemampuan awal yang sama. Sebagaimana Mukhtar (2003, hal. 57) 
menjelaskan bahwa kemampuan awal menunjukkan tingkat pengetahuan dan keterampilan siswa sebelum pembelajaran untuk menuju ke tingkat pengetahuan yang sesuai dengan tujuan pembelajaran yang telah ditetapkan.

2. Proses Pembelajaran Akidah Akhlak dengan metode 'Ibrah Mauizhah dalam model pembelaj-aran Student Teams Achievement Divisions pada Kelas Eksperimen

Setelah peneliti memberikan pretest pada kelas eksperimen dan kontrol, selanjutnya peneliti memberikan treatment. Adapun treatment dengan menggunakan metode Tbrah Manizhah dalam model pembelajaran Student Teams Achievement Divisions diterapkan di kelas eksperimen dengan mengacu kepada pada materi kurikulum 2013 yang didalamnya terdapat kegiatan pendahuluan, kegatan inti, dan kegiatan penutup. Adapun untuk penerapan metode Tbrah Mawizhab dalam model pembelajaran Student Teams Achievement Divisions berlangsung pada kegiatan inti dengan maksud untuk terinternalisasinya nilai-niai yang terkandung dari setiap materi pelajaran sehingga menyentuh qalbu dan dapat menumbuhkan amal perbuatan siswa. Sebagaimana Tafsir (2011, hal. 145) menjelaskan bahwa melalui íbrah dapat membuat kondisi psikis seseorang mengetahui intisari suatu perkara sehingga menyentuh hati dan dapat menumbuhkan amal perbuatan. Dalam tahap ini juga disertai dengan manizhah yang menyentuh, sebagaimana an-Nahlawi (1989, hal. 403) mengemukakan bahwa manizhah merupakan pemberian nasihat dan pengingatan akan kebaikan dan kebenaran dengan cara menyentuh dan qalbu dan menggugah untuk mengamalkannya.

Selain itu, dalam proses pembelajaran diharapkan tingginya aktivitas siswa melalui kegiatan diskusi kelompok. Sebagaimana Warsono dan Hariyanto (2012, hal. 197) mengemukakan bahwa "Dalam STAD mendorong siswa untuk terbiasa bekerja sama dan saling membantu dalam menyelesaikan masalah". Model ini melibatkan lebih banyak peserta didik dan fungsinya untuk meningkatkan aktifitas siswa dalam proes pembelajaran dan mengecek pemahaman siswa terhadap materi pelajaran. Dalam hal ini Abidin (2009, hal. 52) memaparkan bahwa model pembelajaran STAD yaitu:

STAD adalah salah satu bentuk pembelajaran kooperatif tempat siswa belajar secara berkelompok, berdiskusi guna menemukan dan memahami konsep-konsep. Semua anggota kelompok berbagi tanggung jawab. Siswa secara individu diberi suatu tes yang ikut berpengaruh terhadap evaluasi seluruh anggota kelompok. Hasil belajar kelompok tersebut dibandingkan dengan kelompok lainnya guna memperoleh penghargaan.

Setelah selesai berdiskusi kemudian setiap kelompok mempresentasikan hasil yang telah didiskusikan dengan kelompoknya. Dari setiap kelompok tersebut berusaha memahami materi yang disampaikan oleh teman kelompoknya. Kemudian siswa dibimbing oleh guru 
untuk menjelaskan 'ibrah sesuai dengan pokok bahasan yang disajikan. Selanjutnya siswa dibimbing oleh guru untuk menghubungkan ibrah yang telah disampaikan dan mengaitkannya dalam kehidupan sehari-hari. Siswa mengemukakan ibrah dari pengalamannya. Guru merespon ibrah yang disampaikan siswa dan memberikan mavizhah yang menyentuh. Hal ini berlandaskan kepada tahap-tahap metode 'ibrah manizhah yang diungkapkan oleh Syahidin (2009, hal. 120-122) bahwa terdapat beberapa tahapan yaitu tahap orientasi, penyajian ibrah, tahap meyakinkan, tahap internalisasi, tahap evaluasi, tahap penyimpulan dan tahap akhir".

Kegiatan pembelajaran selanjutnya adalah siswa diberikan kuis secara individu oleh guru. Kemudian setelah diberi kuis, siswa dibimbing guru untuk perhitungan skor individu dan kelompok. Pemberian penghargaan diberikan oleh guru untuk tiga kelompok terbaik. Langkah ini sesuai dengan yang diungkapkan oleh Alma, dkk. (2009, hal. 83-84) bahwa terdapat lima langkah yang dilakukan pada STAD yaitu:

a. Tahap penyajian materi. Kegiatan pertama ialah memberikan materi secara klasikal.

b. Tahap kegiatan kelompok. Tahap kerja kelompok siswa diberi lembar tugas, sebagai bahan yang akan dipelajari. Mereka saling berbagi tugas saling membantu, kemudian hasil belajar kelompok diserahkan.

c. Tahap tes individual. Pada tahap tes individu, masing-masing diberi tes lebih kurang 10 menit tentang apa yang sudah ia pelajari, hasil tesnya dicatat dan diarsipkan, yang akan digunakan untuk perolehan skor kelompok.

d. Tahap perhitungan skor perkembangan individu. Tahap perhitungan skor perkembangan individu dilihat perkembangan nilai siswa mulai dari skor awal. Tiap siswa memberikan sumbangan skor maksimal bagi kelompok berdasar skor yang diperolehnya.

e. Tahap pemberian penghargaan kelompok. Tahap pemberian penghargaan kelompok berdasarkan perolehan skor ratarata yang dinyatakan secara kualitatif, baik, baik sekali dan sebagainya.

Secara keseluruhan, treatment dilakukan sebanyak dua kali pertemuan, ditambah dengan dua pertemuan untuk pre-test dan post-test. Adapun materi yang dibahas yaitu bab Keteguhan Iman Abu Bakar ashShiddiq dan Husnushan, Tawadbu, Tasamuh, dan Ta'amun. Untuk penjelasan mengenai langkah-langkah pembelajaran pada setiap pertemuan, dipaparkan pada lampiran Rencana Pelaksanaan Pembelajaran (RPP). Urutan langkah-langkah pembelajaran antara kelas eksperimen dan kelas kontrol tidak jauh berbeda, yang membedakan hanya pada kegiatan intinya saja.

Saat pembelajaran dengan metode Tbrah Manizhah dalam model pembelajaran Student Teams Achievement Divisions terlihat antuasiasme dan keaktifan siswa ketika penyampaian 
ibrah melalui tanyangan video, hal ini karena salah satu kelebihan metode 'ibrah mavizhah yaitu menarik perhatian penyimak mengikuti peristiwa, merenungkan maknanya serta terkesan oleh si pelaku atau peristiwa (Syahidin, 2009, hal. 112). Selain itu, pada saat diskusi siswa terlihat bersungguhsungguh untuk memahami materi, karena tahap selanjutnya akan diberikan kuis secara individu yang hasilnya akan ikut berpengaruh pada seluruh anggota kelompok. Maka, setiap anggota harus berusaha memperoleh nilai maksimal dalam kuis jika kelompok mereka ingin mendapatkan skor yang tinggi. Diungkapkan oleh Soewarso (1998, hal. 22) bahwa kelebihan model STAD yaitu:

a. Membantu siswa mempelajari isi materi pelajaran yang sedang dibahas.

b. Menjadikan siswa mampu belajar berdebat, belajar mendengarkan pendapat orang lain, dan mencatat hal-hal yang bermanfaat untuk kepentingan bersama.

c. Menghasilkan pencapaian belajar siswa yang tinggi serta menambah hargaa diri siswa dan memperbaiki hubungan dengan teman sebaya.

d. Hadiah atau penghargaan yang diberikan akan memberikan dorongan bagi siswa untuk mencapai hasil yang lebih tinggi.

e. Pembentukan kelompokkelompok kecil memudahkan guru untuk memonitor siswa dalam bekerja sama.

\section{Kondisi Akhir Prestasi Belajar Siswa Kelas Eksperimen dan Kelas Kontrol}

Setelah dilakukan treatment, kemudian siswa kelas eksperimen dan kelas kontrol diberikan post-test yang bertujuan untuk mengetahui kondisi akhir prestasi belajar siswa dalam materi keteguhan iman Abu Bakar ash-Shiddiq dan bab husnuzhan, tawadhu, tasamuh, dan ta'awun.

Dari hasil post-test tersebut, menghasilkan bahwa kelas eksperimen memiliki nilai rata-rata post-test sebesar 78,83 dengan interpretasi baik. Adapun untuk distribusi frekuensi interpretasi nilainya yaitu diketahui bahwa terdapat 3 siswa atau $13 \%$ yang memiliki interpretasi nilai sangat baik, kemudian terdapat 13 siswa atau 54\% yang memiliki nilai interpretasi baik, selanjutnya terdapat 6 siswa atau $25 \%$ yang memiliki nilai interpretasi cukup, sedangkan 2 siswa atau $8 \%$ memiliki nilai interpretasi kurang.

Dari hasil perhitungan post-test diperoleh sebanyak $81 \%$ siswa kelas eksperimen yang memahami bab Keteguhan Iman Abu Bakar ashShiddiq. Jika dilihat dari indikator pada bab ini, yang dipahami oleh siswa pada indikator pertama sebesar $86 \%$, indikator kedua sebesar $83 \%$, indikator ketiga sebesar $87 \%$, dan indikator keempat sebesar $69 \%$.

Sedangkan siswa kelas eksperimen yang memahami bab Husnuzhan, Tawadhu, Tasamuh, dan Ta'awun sebanyak 70\%. Jika dilihat dari indikator yang ada pada bab ini, sebesar $83 \%$ yang dipahami siswa pada indikator pertama, sedangkan pada indikator kedua sebesar $72 \%$, 
kemudian indikator ketiga sebesar $68 \%$, dan indikator keempat sebesar $58 \%$.

Mengenai analisis data hasil post-test yang diperoleh siswa kelas kontrol mengahasilkan nilai rata-rata post-test sebesar 64,2 dengan interpretasi nilai cukup. Selanjutnya mengenai distribusi frekuensi post-test kelas kontrol diketahui tidak terdapat siswa yang memiliki interpretasi nilai sangat baik, selanjutnya yang memiliki nilai interpretasi baik sebanyak 6 siswa atau $25 \%$, kemudian yang memiliki interpretasi nilai cukup sebanyak 10 atau $42 \%$, dan yang memiliki interpretasi kurang terdapat 8 siswa atau $33 \%$.

Selanjutnya mengenai hasil posttest yang diperoleh siswa kelas kontrol menghasilkan sebanyak 66\% siswa memahami bab Keteguhan Iman Abu Bakar ash-Shiddiq Jika dilihat dari indikator pada bab ini yang dipahami oleh siswa yaitu indikator pertama sebanyak $66 \%$, indikator kedua sebanyak 52\%, indikator ketiga sebanyak $79 \%$, indikator keempat sebanyak $69 \%$.

Sedangkan mengenai bab Husnuzhan, Tawadbu, Tasamuh, dan Ta'amun yang dipahami oleh siswa kelas kontrol sebanyak 57\%. Jika dilihat dari indikator yang ada, sebanyak $68 \%$ yang dipahami siswa pada indikator pertama, sedangkan pada indikator kedua sebanyak 56\%, kemudian indikator ketiga sebanyak $56 \%$, dan indikator keempat sebanyak $49 \%$.

Kemudian untuk mengetahui adanya peningkatan atau tidak mengenai prestasi belajar siswa kelas eksperimen dan kelas kontrol, dicari dengan gain ternormalisasi. Dari hasil olah data gain ternormalisasi menunjukkan bahwa siswa kelas eksperimen mengalami peningkatan sebesar 0,61 dengan interpretasi sedang. Untuk uji paired sample $T$ Test sig. (2-tailed) yang dihasilkan oleh kelas eksperimen adalah 0,000 . Hal ini menunjukkan bahwa $0,000<0,05$ yang artinya peningkatan prestasi belajar siswa yang terjadi di kelas eksperimen signifikan.

Sedangkan untuk olah data gain ternormalisasi kelas kontrol menunjukkan bahwa siswa kelas kontrol mengalami peningkatan sebesar 0,24 dengan interpretasi rendah. Kemudian untuk uji paired sample $T$ Test sig. (2-tailed) yang dihasilkan oleh kelas kontrol adalah 0,000. Hal ini menunjukkan bahwa $0,000<0,05$ yang artinya peningkatan prestasi belajar siswa yang terjadi di kelas kontrol pun signifikan.

Dengan demikian, dapat disimpulkan bahwa siswa kelas eksperimen dan siswa kelas kontrol sama-sama mengalami peningkatan prestasi belajar setelah dilakukan treatment. Sebagaimana Sudjana (2006, hal. 22) mengemukakan bahwa prestasi belajar merupakan kemampuan-kemampuan yang dimiliki siswa setelah menerima pengalaman belajarnya. Begitupun dengan hasil perhitungan gain ternormalisasi sebagaimana yang telah diketahui bahwa siswa kelas eksperimen yang menggunakan metode Tbrah Mauizhah dalam model pembelajaran Student Teams Acbievement Divisions dan kelas kontrol yang menggunakan metode

TARBAWY: Indonesian Journal of Islamic Education - Vol. 4 No. 2 (2017) | 121 
ceramah, keduanya mengalami peningkatan prestasi belajar yang signifikan.

\section{Efektivitas Metode 'Ibrah Mauizhah dalam Model Pembelajaran Student Teams Achievement Divisions terhadap Prestasi Belajar Siswa pada Mata Pelajaran Akidah Akhlak}

Untuk mengetahui adanya perbedaan yang signifikan atau tidak antara hasil post-test kelas eksperimen dan kelas kontrol, dicari dengan uji hipotesis independent sample t test karena pengujian sebelumnya telah diketahui bahwa distribusi data post-test kelas eksperimen dan kelas kontrol normal dan homogen. Berdasarkan uji hipotesis independent sample $t$ test, diperoleh nilai sig. (2-tailed) sebesar 0,000 yang artinya lebih kecil dari 0,05 .

Maka, sesuai dengan ketentuan bahwa jika nilai sig. (2-tailed) $<0,05 \mathrm{H}_{\mathrm{a}}$ diterima dan $\mathrm{H}_{\mathrm{o}}$ ditolak.

Dari uji independent sample $t$ test tersebut dapat diketahui bahwa terdapat perbedaan yang signifikan antara prestasi belajar siswa kelas eksperimen yang menggunakan metode Ibrah Mauizhah dalam model pembelajaran Student Teams Acbievement Divisions dengan siswa kelas kontrol yang tidak menggunakan metode Tbrah Mauizhah dalam model pembelajaran Student Teams Achievement Divisions. Dengan kata lain, metode Tbrah Mauizhah dalam model pembelajaran Student Teams Achievement Divisions efektif terhadap prestasi belajar siswa pada materi bab Keteguhan Iman Abu Bakar ash-Shiddiq serta bab busnu乏han, tawadhu, tasamub, dan ta'awnn. Hal ini sejalan dengan pendapat Arikunto
(2016, hal. 50-53) yang menjelaskan bahwa karakteristik efektivitas dilihat dari dua aspek yaitu: 1) hasil belajar siswa menunjukkan adanya perbedaan dari pre-test dan post-test, 2) model belajar dikatakan efektif jika terdapat peningkatan hasil belajar.

\section{KESIMPULAN}

Berdasarakan hasil yang diperoleh dari analisis dan pembahasan seluruh tahapan penelitian ini, didapatkan kesimpulan bahwa metode Tbrah Man'izah dalam model pembelajaran Student Teams Achievement Divisions efektif terhadap prestasi belajar siswa pada mata pelajaran Akidah Akhlak di kelas VIII MTs Plus Darul Hufadz Jatinangor Sumedang. Adapun simpulan yang diperoleh dari penelitian ini dapat dirinci sebagai berikut:

1. Kondisi Awal Prestasi Belajar Siswa Kelas Eksperimen dan Kontrol. Nilai rata-rata pre-test kelas eksperimen sebesar 46,33 dengan interpretasi nilai kurang. Begitupun dengan kelas kontrol, ditemukan nilai rata-rata pre-test sebesar 53,83 dengan interpretasi nilai kurang. Hasil pre-test tersebut kemudian diuji dengan uji independent sample $\mathrm{T}$ Test untuk melihat perbedaannya, dari pengujian tersebut diketahui bahwa nilai sig.(2 tailed) sebesar 0,079, yang artinya lebih besar dari 0,05. Dengan demikian, tidak terdapat perbedaan yang signifikan antara nilai rata-rata pre-test kelas eksperimen dan kontrol.

2. Proses Pembelajaran Akidah Akhlak dengan menggunakan metode 
Ibrah Mau'izab dalam model pembelajaran Student Teams Achievement Divisions meliputi kegiatan pendahuluan, kegiatan inti dan penutup. Perbedaannya terletak pada kegiatan inti, yaitu siswa menyampaikan ibrah dari tayangan video. Kemudian siswa berdiskusi secara berkelompok. Siswa dibimbing untuk menjelaskan 'ibrah sesuai dengan pokok bahasan. Kemudian menghubungkan 'ibrah yang telah disampaikan dan mengaitkannya dalam kehidupan sehari-hari. Siswa mengemukakan 'ibrah dari pengalamannya. Guru merespon 'ibrah yang disampaikan siswa dan memberikan mau'izah yang menyentuh. Selanjutnya siswa diberikan kuis secara individu. Kemudian perhitungan skor individu dan kelompok. Pemberian penghargaan kepada tiga kelompok terbaik. Kemudian menyimpulkan materi pembelajaran dan memberi tindak lanjut dengan cara memberi tugas kepada siswa untuk menuliskan 'ibrah dari materi pelajaran yang telah disampaikan.

3. Kondisi Akhir Prestasi Belajar Siswa Kelas Eksperimen dan Kontrol. Nilai rata-rata post-test kelas eksperimen sebesar 78,83 dengan interpretasi nilai baik. Sedangkan, nilai rata-rata post-test kelas kontrol sebesar 64,2 dengan interpretasi nilai cukup. Kemudian untuk data gain ternormalisasi kelas eksperimen mengalami peningkatan sebesar 0,61. Untuk uji paired sample T Test sig. (2tailed) yang dihasilkan oleh kelas eksperimen adalah 0,000. Hal ini menunjukkan bahwa $0,000<0,05$ yang artinya peningkatan prestasi belajar siswa yang terjadi di kelas eksperimen signifikan. Kemudian untuk kondisi akhir prestasi belajar siswa kelas kontrol ditunjukkan oleh gain ternormalisasi mengalami peningkatan sebesar 0,24. Untuk uji paired sample $\mathrm{T}$ Test sig. (2-tailed) yang dihasilkan oleh kelas kontrol adalah 0,000. Hal ini menunjukkan bahwa $0,000<0,05$ yang artinya peningkatan prestasi belajar siswa yang terjadi di kelas kontrol pun signifikan.

4. Efektifitas metode 'Ibrah Mau'izah dalam model pembelajaran Student Teams Acbievement Divisions. Dari uji Independent Sample $\mathrm{T}$ Test, diperoleh nilai sig.(2-tailed) sebesar 0,000 yang artinya lebih kecil dari 0,05. Maka, sesuai dengan ketentuan bahwa jika nilai sig. (2-tailed) $<0,05 \mathrm{Ha}$ diterima dan Ho ditolak. Dengan demikian, dapat disimpulkan bahwa terdapat perbedaan yang signifikan antara prestasi belajar siswa kelas eksperimen dan siswa kelas kontrol. Oleh karena itu, metode 'Tbrah Mau'izah dalam model pembelajaran Student Teams Achievement Divisions efektif terhadap prestasi belajar siswa pada mata pelajaran Akidah Akhlak, terutama dalam bab Keteguhan Iman Abū Bakar aș-Ṣiddiq dan bab Husnuzan, Tawàdu', Tasāmuh, dan Ta'àwun.

\section{REFERENSI}


Alma, B., Mulyadi, H., Razati, G., \& S, B. L. (2009). Guru Profesional Menguasai Metode dan Terampil Mengajar). Bandung: Alfabeta.

Alfiah, H. Y. (2014). Aplikasi Paradigma Konstruksivistik Model Kooperatif STAD untuk Meningkatkan Kualitas Pembelajaran PAI di Kelas IV SD Taruna Surabaya. Jurnal Pendidikan Agama Islam, 2(2), 234-272.

Alsardary, S., \& Blumberg, P. (2009). Interactive, Learner-Centered Methods of Teaching Mathematics. Jurnal Primus, 19(4), 401-416. https://doi.org/10.1080/10511 970701678596

An-Nahlawi, A. (1989). Prinsip-prinsip dan Metoda Pendidikan Islam. Bandung: Diponegoro.

Arikunto, S. (2016). Dasar-dasar Evaluasi Pendidikan. Jakarta: Bumi Aksara.

Armen. (2009). Analisis Efektivitas Kebijakan Link and Match pada Sekolah Menengah Kejuruan (SMK) di Sumatera Barat. Jurnal Guru Pembelajaran di Sekolah Dasar dan Menengah, 130.

Balfakih, N. M. A. (2003). The Effectiveness of Student TeamAchievement Division (STAD) for Teaching High School Chemistry in the United Arab Emirates. International Journal of Science Education, 25(5), 605-624. https://doi.org/10.1080/09500 690110078879

Cornford, I. (2002). Learning-to-learn strategies as a basis for effective lifelong learning. International
Journal of Lifelong Education, 21(4), 357-368.

https://doi.org/10.1080/02601

370210141020

Darwis, A. (2014). Metode Penelitian Pendidikan Islam. Jakarta: Rajawali Pers.

Djamarah, S. B., \& Zain, A. (2006). Strategi Belajar Mengajar. Jakarta: PT Rineka Cipta.

Emzir. (2015). Metodologi Penelitian Pendidikan: Kuantitatif dan Kualitatif. Jakarta: Rajawali Pers.

Faisol, A. (2013, Desember 9). Di Sekolah Siswa Teladan di Luar Mencuri Motor. Dipetik Januari 1, 2017, dari Kompas: http://internasional.kompas.co $\mathrm{m} / \mathrm{read} / 2013 / 12 / 09 / 2003374 /$

Di.Sekolah.Siswa.Teladan.di.Lua r.Mencuri.Motor

Ghaith, G. (2004). Correlates of the implementation of the STAD cooperative learning method in the English as a foreign language classroom. International Journal of Bilingual Education and Bilingualism, 7(4), 279-294. https://doi.org/10.1080/13670 050408667813

Hamid Reza alavi. (2013). Islamic Educational Goals, Methods, and Content, with Emphasis on Shia' Faith. Journal of Research on Christian Education, 22(1), 4-20. https://doi.org/10.1080/10656 219.2013.769817

Komalasari, K. (2011). Pembelajaran Kontekstual Konsep dan Aplikasi. Bandung: PT Refika Aditama.

Majid, A. (2012). Belajar dan Pembelajaran. Bandung: PT Remaja Rosdakarya. 
McQueen, H., \& Webber, J. (2013). What is an Effective Learner? A Comparison of Further Education Students' Views with a Theoretical Construction of Effective Learners. Journal of Further and Higher Education, 37(January 2015), 715-735. https://doi.org/10.1080/03098 77X.2012.684040

Mujib, A., \& Mudzakkir, J. (2014). Imu Pendidikan Islam. Jakarta: Kencana Prenada Media Group. Mukhtar. (2003). Desain Pembelajaran Pendidikan Agama Islam. Jakarta: CV Misaka Galiza.

Mulyasa, E. (2009). Menjadi Guru Profesional Menciptakan

Pembelajaran Kreatif dan Menyenangkan. Bandung: PT Remaja Rosdakarya.

Nasih, A. M., \& Kholidah, L. N. (2009). Metode dan Teknik Pembelajaran Pendidikan Agama Islam. Bandung: PT Refika Aditama.

Prastowo, A. (2014). Pembelajaran Konstruktivistik-Scientifik untuk Pendidikan Agama di Sekolah/Madrasah. Jakarta: Rajawali Pers.

Remus, W. (1978). An effective learning system for large quantitative methods courses. International Journal of Mathematical Education in Science and Technology, 9(1), 51-64. https:/ / doi.org/10.1080/00207 39780090108

Rusman, T. (2011). Faktor-Faktor yang Berpengaruh Terhadap Prestasi Belajar Ekonomi. Jurnal Pendidikan Progresif, 200-201.
Said, A. (2006). Efektivitas Computer Assisted Instruction (CAI) Terhadap Hasil Belajar Matematika Siswa Sekolah Menengah Umum Negeri. Jurnal Pendidikan dan Kebudayaan, 98.

Soewarso. (1998). Menggunakan Strategi Komparatif Learning di dalam Pendidikan Ilmu Sosial No. 1. Edukasi, 22.

Sudjana. (2006). Metode Statistik. Bandung: Tarsiko.

Sugiyono. (2016). L Metode Penelitian Pendidikan (Pendekatan Kuantitatif, Kualitatif, dan R\&D). Bandung: Alfabeta.

Suprijono, A. (2012). Cooperative Learning Teori dan Aplikasi PAIKEM. Yogyakarta: Pustaka pelajar.

Suyono, \& Hariyanto. (2012). Belajar dan Pembelajaran Teori dan Konsep. Bandung: PT Remaja Rosdakarya.

Syahidin. (2009). Menelusuri Metode Pendidikan dalam Al-Quran. Bandung: Alfabeta.

Tafsir, A. (2011). Ilmu Pendidikan Perspektif Islam. Bandung: PT Remaja Rosdakarya.

Trianto. (2012). Mendesain Model Pembelajaran Inovatif Progresif: Konsep, Landasan, dan Implementasinya pada Kurikulum Tingkeat Satuan Pendidikan (KTSP). Jakarta: Kencana Predana Media Group.

Umar, B. (2010). Ilmu Pendidikan Islam. Jakarta: Amzah.

Uno, H. B. (2009). Model Pembelajaran. Jakarta: PT Bumi Aksara.

TARBAWY: Indonesian Journal of Islamic Education - Vol. 4 No. 2 (2017) | 125 
Wahab, A. A. (2008). Metode dan Modelmodel Mengajar Ilmu Pengetahuan Sosial (IPS). Bandung: Alfabeta.

Warsono, \& Hariyanto. (2012). Pembelajaran Aktif. Bandung: PT Remaja Rosdakarya.

Widdah, M. E., Suryana, A., \& Musyadad, K. (2012). Kepemimpinan Berbasis Nilai dan Pengembangan Mutu Madrasah. Bandung: Alfabeta. 